\title{
APPLICATION OF INTEGRATED WATER QUALITY INDEX (IWQI) MODEL AND DISSOLVED OXYGEN SATURATION PERCENTAGE FOR COMPARATIVE EVALUATION OF WATER QUALITY AND APPROPRIACY OF RIVER GANGA AT RISHIKESH AND HARDWAR
}

\author{
Sangeeta Madan and Deepika Sharma ${ }^{\bowtie}$ \\ Department of Environmental Sciences, Kanya Gurukul Campus, Gurukul Kangri \\ Vishwavidhyalaya, Haridwar -249403 (Uttarakhand) India \\ ${ }^{\circledR}$ Corresponding Author: deepikasangtani@gmail.com
}

\begin{abstract}
Integrated Water Quality Index (IWQI) succor intricates water quality data into rationalized insight to determine water quality from a source or any water supply in an exceedingly consistent and unbiased manner. Ganga River, being the source of water supply in the entire Indo-Gangetic region is diminishing due to poor water quality. It is highly indeterminate to determine the status of a river's water quality; hence, frequent monitoring of river water is necessary. The present study was undertaken to comparatively evaluate the Percent Saturation of Dissolved Oxygen and integrated water quality index of River Ganga at Rishikesh and Hardwar. Six parameters were selected to derive the IWQI for determining water potential for a total of 14 sampling sites and were compared with BIS Standards. The outcomes revealed that the water quality of the river falls from good to marginal and about to borderline to poor status, thus it concludes that the quality of river water in its native region is on the verge of declination.

Keywords: Water Quality, Ganga, River, Monitoring, Dissolved Oxygen, Pollution, Variation
\end{abstract}

RASĀYAN J. Chem., Vol. 14, No.3, 2021

\section{INTRODUCTION}

Air, Water, and Soil are considered an elementary source of life on earth. According to the Vedic context in Indian Ideology, they form an integral part of "Panchmahabhootas" that includes -Air, Water, Soil, Fire, and Ether. Contamination to any of this subtle essence leads to alterations in their physicochemical and biological properties leading to ecological imbalances and potential threats to human survival. ${ }^{1,2}$ Water, being the relevant and abundant compound of the ecosystem is necessary for the vitality of the living organisms. ${ }^{3}$ Even NASA's motto "Follow the water" is far enough to define its supremacy in the hunt for extraterrestrial life. ${ }^{4}$ Surface water, particularly stream systems is a very important supply of water for numerous functions just like the source of drinkable supply, irrigation, industrial manufacturing units, and municipal corporation water provides, and waste disposal, trans-river traveling, fishing or trawling, boating, amusement, and recreation. ${ }^{5,6}$ Some of the rivers pose great aesthetic values, and a center of religio-touristic activities. ${ }^{7}$ River Ganga is one of the foremost sacred rivers of India having historical, mythological, cultural, and economic importance. It is continuously serving as a lifeline for the whole Indo-Gangetic region. Unfortunately, it is now under the clasps of the devil pollution and ranked as the five most polluted, and top ten threatened rivers of the world in 2007 by the World Wide Fund for Nature(WWF). ${ }^{8}$

The state of a river profoundly depends upon its quality of water which changes regularly and seasonally due to various atmospheric and riverine system-based factors that is why regular monitoring of river water is required. ${ }^{9}$ The best method to detect and evaluate water quality trends and pollution is with indices that are widely classified as physicochemical indices and biological indices. Physicochemical indices demonstrate the impact of physicochemical parameters associated with the surface water system 
while biological indices reflect biological information calculated by identifying species composition of the provided sample, diversity and variability among the species, their distribution pattern, existence or absenteeism of indicator species, and much more. ${ }^{10}$ Here, a prominent attempt has been made to compute the water quality and appropriacy of watercourse Ganga using Dissolved Oxygen Percent Saturation and Integrated Water Quality Index Model(IWQI) in religio-touristic cities of Uttarakhand that is Rishikesh and Hardwar based on several physicochemical observations.

\section{Site Description}

\section{EXPERIMENTAL}

Rishikesh, situated in the lapse of Garhwal Himalayas renowned as Yoga capital is in the state of Uttarakhand, extended from latitude $30^{\circ} 072$ in the north to longitude $78^{\circ} 172$ in the east with an average elevation of 372 meters and population of 102,138 as per the 2011 census of India. Water samples were collected from seven sites in Rishikesh, that is Shivpuri, Laxman Jhula, Ram Jhula, Chandrabhaga, Triveni Ghat, Sai Ghat, and Pashulok Barrage.

Hardwar, the center of Hindu Pilgrimage, present at the boundary between Himalayan foothills in the North and the most fertile Indo- Gangetic plain in the South along the bank of river Ganga. It extends from latitude 29.942 in the north to longitude $78^{\circ} 162$ in the east with an average elevation of 314 meters and a population of 2,28,832 as per the 2011 census of India. Water samples were collected from seven sites in Haridwar, i.e. Saptrishi Ghat, Sarvanand Ghat, Dhobhi Ghat, Har ki Pauri, Chandi Ghat, Premnagar Ghat, and Jatwada Pul.

The water supply of the Ganga Riverine System is to some extent rely on the rains initiated by monsoon winds in July till October and also on the flow due to the melting of glaciers of the Himalayas in the summer season from April to June. ${ }^{11}$ The frequent water quality monitoring is highly relevant in these regions because these regions are also surrendering themselves to the pollution and the water quality is diminishing due to exploitations and encroachments.

\section{Data Collection and Analysis}

Water samples were stockpiled from the distinct sites during different seasons at Rishikesh and Hardwar over one year (January 2017 to December 2017). The water samples from river Ganga were collected using the grab sampling method, monthly. Some parameters were evaluated on the spot followed by laboratory analysis as per the standard methods. ${ }^{12,13}$ In the present study, for the calculation of water quality using the Integrated Water Quality Index, a total of seven parameters were considered such as $\mathrm{pH}$, DO (mg/L), BOD (mg/L), Alkalinity (mg/L), Total Hardness (mg/L), TDS (mg/L), Electrical Conductivity $(\mu \mathrm{mho} / \mathrm{cm})$.

\section{Dissolved Oxygen Percent Saturation and Integrated Water Quality Index (IWQI) model.}

Dissolved Oxygen is an essential parameter to define the health of an aquatic body as well as organisms. The substantial amount of oxygen that imperatively dissolves in water can be variable due to daily and seasonal patterns, water temperature, water salinity, and elevation of the place. The maximum solubility of oxygen in water at $1 \mathrm{~atm}$ pressure (standard air pressure at sea level) ranges from about $15 \mathrm{mg} / \mathrm{L}$ at $0^{\circ} \mathrm{C}$ to $8 \mathrm{mg} / \mathrm{L}$ at $30^{\circ} \mathrm{C}$.

$$
\text { DO } \% \text { Saturation }=\frac{\text { Actual Dissolved Oxygen }(\mathrm{mg} / \mathrm{L})}{\text { Max Dissolved Oxygen Concentration }(\mathrm{mg} / \mathrm{L})} \text { at the same water temperature. }
$$

The resulting values of percentage saturation so obtained can be generalized and compared through (Table-1).

Table-1: The Percentage Saturation of Dissolved Oxygen to Analyze the Status of Water Quality of the Aquatic

\begin{tabular}{c|c|c|c}
\hline$>90$ & $89-75$ & $74-66$ & $<60$ \\
\hline Excellent & Good & Fair & Poor \\
\hline \multicolumn{4}{l}{ Source $:$ http://dep.wv.gov/WWE/getinvolved/sos/Documents/SOSKit/DOSaturation.pdf ${ }^{14}$}
\end{tabular}


The simplest and pronounced way to demonstrate the water quality trends in the river is with indices as it reduces the massive amount of complex data into a simple and comprehensible form that is easy to understand and help in the formulation of trend analysis, enforcement of standards, shape sound public policies, development of scientific research, resource allocation based on priorities, ranking of the locations, implementation of water quality improvement and management programs. ${ }^{15}$

Integrated Water Quality Index, is one of the flexible indexes which is unbiased, time-efficient, handy to use, and highly predictable. According to this model, the directly practiced or widely used indices assumed that the values of water quality parameters underneath the desirable limit are safe to drink but it influences and poses effect on the appropriateness of water as deficiency makes wellbeing or healthrelated issues; so it is basic to consider both the edge limits(desirable and permissible limits) to evaluate the fitness of drinking water. It can be calculated by the following equation:

Where,

$$
\text { IWQI } i=\sum_{j=1}^{n} S I i j
$$

$\mathrm{SI}_{\mathrm{ij}}=$ sub-index value of $\mathrm{i}^{\text {th }}$ sample and $\mathrm{j}^{\text {th }}$ water quality parameter.

$\mathrm{SI}_{\mathrm{ij}}$ can be calculated based on conditions-

$\mathrm{SI}_{1}=0$ (if $\left.\mathrm{DL} \leq \mathrm{Pi} \geq \mathrm{MPL}\right)$

$\mathrm{SI}_{2}=(\mathrm{DL}-\mathrm{Pi}) / \mathrm{DL}($ if $\mathrm{Pi} \leq \mathrm{DL})$

$\mathrm{SI}_{2}=(\mathrm{DL}-\mathrm{Pi}) / \mathrm{DL}($ if $\mathrm{Pi} \geq \mathrm{MPL})$

Where,

$\mathrm{SI}=\mathrm{Sub}$ Index

$\mathrm{Pi}=$ Water quality of ith parameter

$\mathrm{DL}=$ Desirable Limit

MPL $=$ Modified permissible limit

Desirable limits and permissible limits are provided by environmental agencies like BIS, ICMR, WHO, etc. Modified Permissible Limits can be calculated as-

$$
\text { Modified Permissible Limit ( MPL ) = Permissible Limit - (20\% Range) }
$$

The range can be calculated as-

$$
\text { Range }=\text { Permissible limit }(\text { PL }) \text { - Desirable limit ( DL ) }
$$

Since it is incredibly difficult to restore the aquifer to its original state after it has been polluted, the $20 \%$ shortage was used to warn the situation until it reached the limit level of pollution. This shortfall percent is highly adaptable and can be adjusted according to the needs of the researcher. ${ }^{16}$ The classification criterion of IWQI for water quality is mentioned in (Table-2).

Table-2: Classification Criterion of IWQI

\begin{tabular}{c|c|c}
\hline W Q I Values & Class & Explanation \\
\hline$<1$ & Excellent & Excellent for Drinking Purpose \\
\hline $1-2$ & Good & Good for Drinking Purpose \\
\hline $2-3$ & Marginal & Acceptable for Domestic Purpose \\
\hline $3-5$ & Poor & Not Suitable for Drinking Purpose \\
\hline$>5$ & Unsuitable & Unacceptable \\
\hline
\end{tabular}

\section{Physicochemical Analysis, Trends, and Variability}

\section{RESULTS AND DISCUSSION}

The Surface water quality of waterway Ganga at Rishikesh and Hardwar is examined utilizing distinctive physicochemical parameters such as Temperature, $\mathrm{pH}$, Dissolved Oxygen (DO), Biological Oxygen Demand (BOD), Total Alkalinity (TA), Total Hardness (TH), Total Dissolved Solids (TDS), and Electrical Conductivity (E.C.) at fourteen distinctive locales of the study zone and the totaled comes about 
RASĀYAN J. Chem.

Vol. 14 | No. 3 |1643-1652| July - September | 2021

were reported in (Tables-3,4) for Rishikesh and Hardwar, respectively. A certain magnificent trend is distinguished within the water quality of these regions when month to month analyzed.

Temperature governs the water quality of any source by affecting its chemical properties, reaction mechanism, and bionomics. It also affects the solubility of gases like oxygen in the water as the temperature increases the solubility of gases in water decreases while mineral content increases or viceversa so tepid water is polluted as compared to normal or frigid water. ${ }^{17}$ In the present study, the temperature of River Ganga was recorded maximum in September $\left(23.47 \pm 0.58{ }^{\circ} \mathrm{C}\right)$ and minimum in January $\left(15.74 \pm 0.74{ }^{\circ} \mathrm{C}\right)$ while in Hardwar, the maximum temperature was recorded in June $(25.24 \pm 0.40$ ${ }^{\circ} \mathrm{C}$ ) and minimum in January $\left(12.14 \pm 0.85^{\circ} \mathrm{C}\right)($ Fig.-1). Similar variations were observed by Matta while exploring the pollution status of the River Ganga in Uttarakhand. ${ }^{18}$

$\mathrm{pH}$ determines the acidity or basicity of the solution. The recommended range for $\mathrm{pH}$ of the water body is 6.5-8.5, any prominent changes in $\mathrm{pH}$ may lead to deterioration of water quality and effects metabolic activities of its aquatic community. ${ }^{19}$ The maximum $\mathrm{pH}$ value $(7.82 \pm 0.33)$ and the minimum $\mathrm{pH}$ value (7.26 \pm 0.07$)$ was recorded at Rishikesh while the maximum $\mathrm{pH}$ value $(7.94 \pm 0.07)$ and minimum $\mathrm{pH}$ value $(7.26 \pm 0.07)$ was found at Hardwar. All the values are within the range of recommended values (Fig.-2). The Dissolved Oxygen values demonstrate the extent of pollution in water bodies and their ability to support aquatic life. The maximum D.O. value $(10.90 \pm 0.36 \mathrm{mg} / \mathrm{L})$ and the minimum D.O value $(8.03 \pm 0.25)$ was recorded at Rishikesh while the maximum D.O. value $(9.65 \pm 0.20 \mathrm{mg} / \mathrm{L})$ and minimum D.O. value $(8.55 \pm 0.09 \mathrm{mg} / \mathrm{l})$ was found at Hardwar. All the values are within the range of recommended values (Fig.-3). Similar trends were observed by Haritash et al., during his evaluation of water quality and its suitability analysis of the River Ganga in Rishikesh, India. ${ }^{20}$

Maximum B.O.D value $(1.30 \pm 0.00) \mathrm{mg} / \mathrm{L}$ and minimum value $(0.88 \pm 0.14) \mathrm{mg} / \mathrm{L}$ were recorded in at Rishikesh while The maximum B.O.D value $(1.47 \pm 0.17) \mathrm{mg} / \mathrm{L}$ and minimum value $(0.98 \pm 0.06) \mathrm{mg} / \mathrm{L}$ were recorded Hardwar(Fig.-4). Similar observations were recorded by Sharma and Madan while examining the pollution status of river Ganga at Rishikesh and Hardwar. ${ }^{9}$

Table-3: Monthly Phenomenal Trends in Physicochemical Parameters at Rishikesh

\begin{tabular}{c|c|c|c|c|c|c|c|c}
\hline $\begin{array}{c}\text { Parameters } \\
\text { Months } \downarrow\end{array}$ & $\begin{array}{c}\text { Temp. } \\
\left({ }^{\circ} \mathrm{C}\right)\end{array}$ & $\mathrm{pH}$ & $\begin{array}{c}\mathrm{DO} \\
(\mathrm{mg} / \mathrm{L})\end{array}$ & $\begin{array}{c}\text { BOD } \\
(\mathrm{mg} / \mathrm{L})\end{array}$ & $\begin{array}{c}\text { Total } \\
\text { Alkalinity } \\
(\mathrm{mg} / \mathrm{L})\end{array}$ & $\begin{array}{c}\text { Total } \\
\text { Hardness } \\
(\mathrm{mg} / \mathrm{L})\end{array}$ & $\begin{array}{c}\text { TDS } \\
(\mathrm{mg} / \mathrm{L})\end{array}$ & $\begin{array}{c}\text { E.C } \\
(\mu \mathrm{mho} / \mathrm{cm}) .\end{array}$ \\
\hline January & $15.74 \pm 0.74$ & $7.32 \pm 0.06$ & $10.31 \pm 0.34$ & $0.88 \pm 0.14$ & $71.14 \pm 3.11$ & $87.00 \pm 6.07$ & $84.42 \pm 3.62$ & $223.17 \pm 5.86$ \\
\hline February & $16.54 \pm 0.50$ & $7.24 \pm 0.11$ & $9.77 \pm 0.43$ & $0.95 \pm 0.18$ & $77.28 \pm 4.30$ & $89.00 \pm 3.42$ & $93.71 \pm 2.80$ & $227.23 \pm 5.32$ \\
\hline March & $18.74 \pm 0.59$ & $7.37 \pm 0.27$ & $9.25 \pm 0.45$ & $0.99 \pm 0.18$ & $80.71 \pm 6.22$ & $87.71 \pm 8.04$ & $94.42 \pm 2.96$ & $205.81 \pm 7.08$ \\
\hline April & $20.12 \pm 0.53$ & $7.44 \pm 0.28$ & $8.88 \pm 0.34$ & $1.06 \pm 0.20$ & $76.42 \pm 6.58$ & $87.14 \pm 6.52$ & $85.42 \pm 4.82$ & $208.53 \pm 12.63$ \\
\hline May & $21.51 \pm 0.93$ & $7.45 \pm 0.35$ & $8.41 \pm 0.33$ & $1.12 \pm 0.18$ & $76.42 \pm 6.01$ & $100.71 \pm 8.09$ & $102.14 \pm 3.26$ & $246.23 \pm 10.00$ \\
\hline June & $22.08 \pm 0.99$ & $7.74 \pm 0.41$ & $8.15 \pm 0.28$ & $1.17 \pm 0.14$ & $74.14 \pm 7.55$ & $106.57 \pm 9.22$ & $103.71 \pm 2.24$ & $251.79 \pm 8.01$ \\
\hline July & $23.17 \pm 0.99$ & $7.74 \pm 0.18$ & $8.03 \pm 0.25$ & $1.30 \pm 0.00$ & $72.57 \pm 4.95$ & $91.71 \pm 5.47$ & $101.57 \pm 2.79$ & $250.90 \pm 9.73$ \\
\hline August & $23.41 \pm 0.60$ & $7.82 \pm 0.33$ & $8.29 \pm 0.33$ & $1.20 \pm 0.14$ & $73.28 \pm 6.30$ & $88.71 \pm 4.75$ & $94.57 \pm 3.90$ & $234.20 \pm 9.94$ \\
\hline September & $23.47 \pm 0.58$ & $7.58 \pm 0.21$ & $8.44 \pm 0.26$ & $1.19 \pm 0.14$ & $74.28 \pm 5.21$ & $89.85 \pm 4.37$ & $96.14 \pm 1.75$ & $238.25 \pm 4.29$ \\
\hline October & $21.05 \pm 0.44$ & $7.78 \pm 0.18$ & $9.27 \pm 0.32$ & $1.01 \pm 0.19$ & $72.00 \pm 3.74$ & $87.21 \pm 4.40$ & $93.85 \pm 1.90$ & $232.95 \pm 6.78$ \\
\hline November & $19.68 \pm 0.42$ & $7.64 \pm 0.17$ & $9.83 \pm 0.23$ & $0.98 \pm 0.20$ & $89.97 \pm 6.49$ & $82.17 \pm 3.47$ & $88.71 \pm 2.16$ & $221.30 \pm 5.39$ \\
\hline December & $16.68 \pm 0.41$ & $7.56 \pm 0.07$ & $10.90 \pm 0.36$ & $0.94 \pm 0.18$ & $68.57 \pm 2.71$ & $82.14 \pm 3.15$ & $84.17 \pm 2.26$ & $211.65 \pm 6.89$ \\
\hline
\end{tabular}

Table-4: Monthly Phenomenal Trends in Physicochemical Parameters at Hardwar

\begin{tabular}{c|c|c|c|c|c|c|c|c}
\hline $\begin{array}{c}\text { Parameters } \rightarrow \\
\text { Months }\end{array}$ & $\begin{array}{c}\text { Temp. } \\
\left({ }^{\circ} \mathrm{C}\right)\end{array}$ & $\mathrm{pH}$ & $\begin{array}{c}\mathrm{DO} \\
(\mathrm{mg} / \mathrm{L})\end{array}$ & $\begin{array}{c}\text { BOD } \\
(\mathrm{mg} / \mathrm{L})\end{array}$ & $\begin{array}{c}\text { Total } \\
\text { Alkalinity } \\
(\mathrm{mg} / \mathrm{L})\end{array}$ & $\begin{array}{c}\text { Total } \\
\text { Hardness } \\
(\mathrm{mg} / \mathrm{L})\end{array}$ & $\begin{array}{c}\text { TDS } \\
(\mathrm{mg} / \mathrm{L})\end{array}$ & $\begin{array}{c}\text { E.C } \\
(\mu \mathrm{mho} / \mathrm{cm}) .\end{array}$ \\
\hline January & $12.14 \pm 0.85$ & $7.62 \pm 0.06$ & $9.44 \pm 0.17$ & $0.98 \pm 0.06$ & $75.71 \pm 3.06$ & $82.28 \pm 3.42$ & $109.57 \pm 5.77$ & $273.6 \pm 14.49$ \\
\hline February & $15.85 \pm 0.26$ & $7.73 \pm 0.04$ & $9.40 \pm 0.10$ & $1.00 \pm 0.05$ & $74.00 \pm 1.44$ & $80.14 \pm 2.14$ & $114.28 \pm 6.31$ & $272.37 \pm 20.22$ \\
\hline March & $18.28 \pm 0.42$ & $7.66 \pm 0.05$ & $9.24 \pm 0.08$ & $1.19 \pm 0.13$ & $76.28 \pm 2.06$ & $84.57 \pm 2.53$ & $113.14 \pm 7.09$ & $287.52 \pm 15.64$ \\
\hline April & $20.71 \pm 0.42$ & $7.44 \pm 0.09$ & $9.02 \pm 0.32$ & $1.32 \pm 0.18$ & $74.85 \pm 3.77$ & $84.85 \pm 4.67$ & $101.57 \pm 5.04$ & $253.56 \pm 12.71$ \\
\hline May & $23.75 \pm 0.18$ & $7.27 \pm 0.12$ & $8.91 \pm 0.57$ & $1.38 \pm 0.19$ & $97.14 \pm 14.20$ & $139.71 \pm 20.79$ & $162.85 \pm 46.64$ & $400.18 \pm 94.20$ \\
\hline June & $25.24 \pm 0.40$ & $7.26 \pm 0.07$ & $8.80 \pm 0.43$ & $1.43 \pm 0.17$ & $119.14 \pm 10.62$ & $149.71 \pm 6.22$ & $131.42 \pm 12.43$ & $298.7 \pm 39.67$ \\
\hline July & $24.04 \pm 0.92$ & $7.61 \pm 0.05$ & $8.95 \pm 0.20$ & $1.15 \pm 0.08$ & $81.71 \pm 7.42$ & $101.42 \pm 5.44$ & $110.85 \pm 3.75$ & $276.48 \pm 9.26$ \\
\hline August & $24.57 \pm 0.20$ & $7.94 \pm 0.07$ & $8.67 \pm 0.04$ & $1.15 \pm 0.07$ & $84.00 \pm 2.58$ & $98.85 \pm 2.26$ & $90.57 \pm 1.17$ & $224.32 \pm 3.15$ \\
\hline
\end{tabular}


RASĀYAN J. Chem.

Vol. 14 | No. 3 |1643-1652| July - September | 2021

\begin{tabular}{c|c|c|c|c|c|c|c|c}
\hline September & $24.00 \pm 0.21$ & $7.74 \pm 0.12$ & $8.55 \pm 0.09$ & $1.15 \pm 0.19$ & $79.14 \pm 2.38$ & $89.42 \pm 2.25$ & $93.00 \pm 1.23$ & $232.3 \pm 3.14$ \\
\hline October & $22.24 \pm 0.42$ & $7.38 \pm 0.14$ & $8.68 \pm 0.12$ & $1.47 \pm 0.17$ & $114.86 \pm 13.47$ & $148.2 \pm 19.82$ & $139.00 \pm 28.13$ & $339.5 \pm 73.78$ \\
\hline November & $19.75 \pm 0.44$ & $7.49 \pm 0.18$ & $8.98 \pm 0.06$ & $1.29 \pm 0.14$ & $108.56 \pm 14.25$ & $135.85 \pm 14.83$ & $121.3 \pm 8.26$ & $267.5 \pm 17.42$ \\
\hline December & $16.96 \pm 0.41$ & $7.81 \pm 0.08$ & $9.65 \pm 0.20$ & $1.04 \pm 0.08$ & $92.82 \pm 2.36$ & $106.14 \pm 5.49$ & $109.86 \pm 7.36$ & $237.93 \pm 19.34$ \\
\hline
\end{tabular}

Natural alkalinity is caused by dissolved carbonate ions, bicarbonates ions of Sodium, Calcium, and Magnesium present in water. In the present study, the maximum alkalinity $(89.97 \pm 6.49) \mathrm{mg} / \mathrm{l}$ and minimum value $(68.57 \pm 2.71) \mathrm{mg} / \mathrm{L}$ were recorded at Rishikesh while The maximum alkalinity

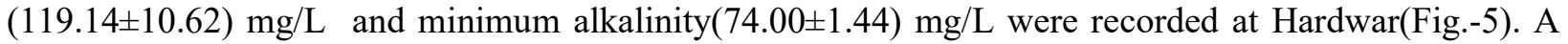
similar range of values (70-144 mg/L) was observed by Haritash et al., while examining the water quality and the suitability analysis of river Ganga in Rishikesh. ${ }^{20}$

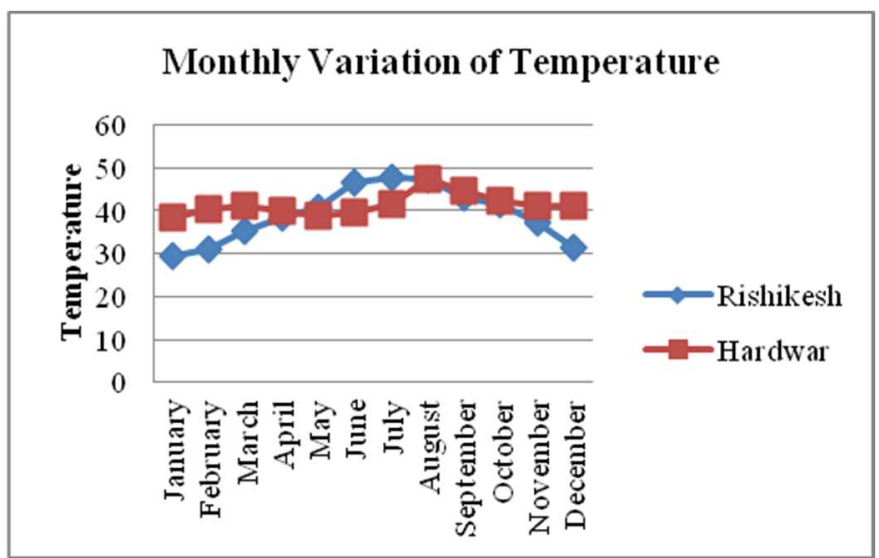

Fig.-1: Monthly Variation of Temperature

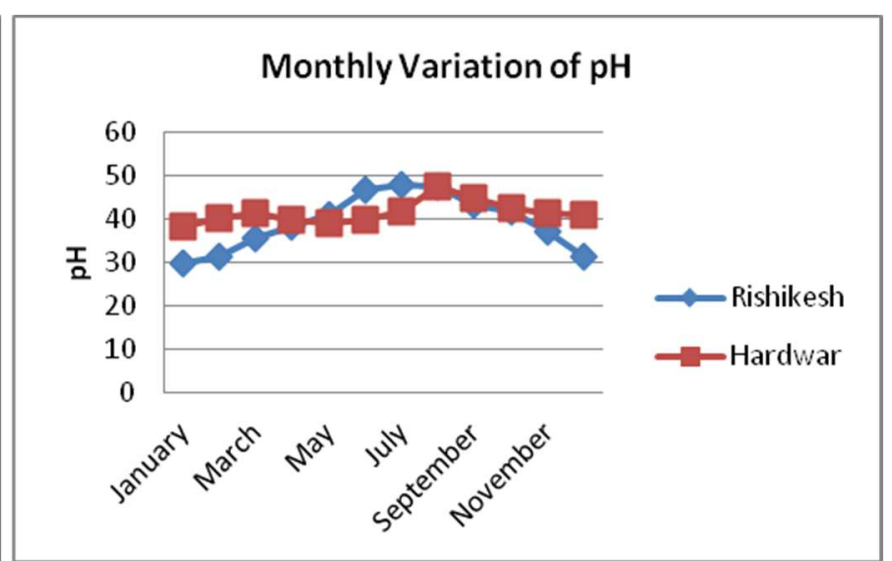

Fig.-2: Monthly Variation of $\mathrm{pH}$
Monthly Variation of Dissolved Oxygen

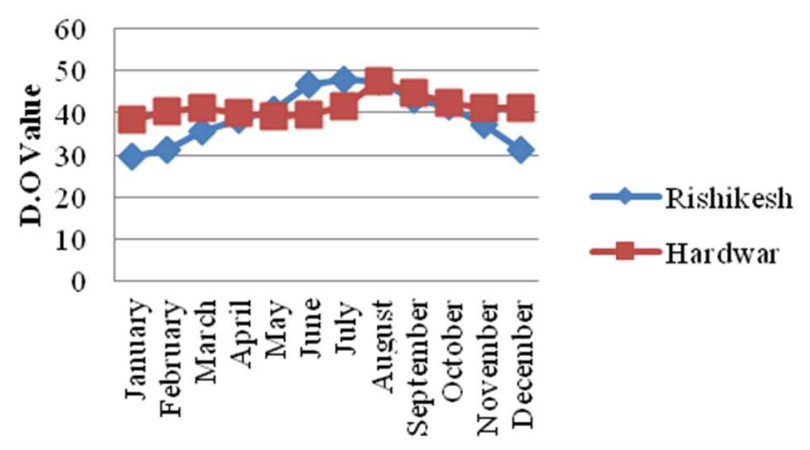

Fig.-3: Monthly Variation of Dissolved Oxygen

\section{Monthly Variation of Biological Oxygen Demand}

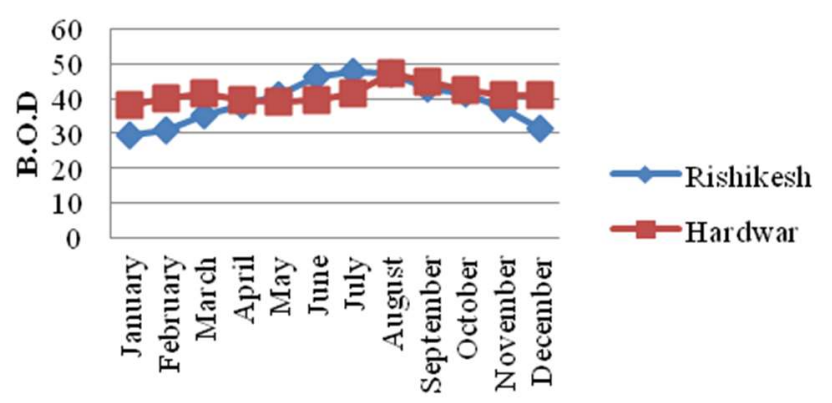

Fig.-4: Monthly Variation of Biological Oxygen Demand

The Total Hardness( $\mathrm{TH})$ in river water is conferred by the presence of Carbonates, Bicarbonates, Chlorides, Sulphates, etc. of Calcium and Magnesium chiefly, whereas, some other chemical substances also determine it. ${ }^{21}$ In the present study maximum hardness $(106.57 \pm 9.22) \mathrm{mg} / \mathrm{L}$ and minimum $(82.14 \pm 3.15) \mathrm{mg} / \mathrm{L}$ was recorded at Rishikesh while maximum hardness $(149.71 \pm 6.22) \mathrm{mg} / \mathrm{L}$ and minimum $(80.14 \pm 2.14) \mathrm{mg} / \mathrm{L}$ was recorded at Hardwar which is under the permissible limit as prescribed by ICMR (Fig.-6).

Solids present in water, either in solution or in suspension form passed through a distinguish fiber filter. The solids retained on the top of the filter are known as suspended solids and which passed through the filter are known as dissolved solids. ${ }^{22}$ In the present study, the maximum TDS value (103.71 \pm 2.24$) \mathrm{mg} / \mathrm{L}$ and minimum TDS value $(84.17 \pm 2.26) \mathrm{mg} / \mathrm{L}$ at Rishikesh while The maximum TDS value $(162.85 \pm 46.64) \mathrm{mg} / \mathrm{L}$ and minimum TDS value $(90.57 \pm 1.17) \mathrm{mg} / \mathrm{L}$ was recorded at Hardwar (Fig.-7). 


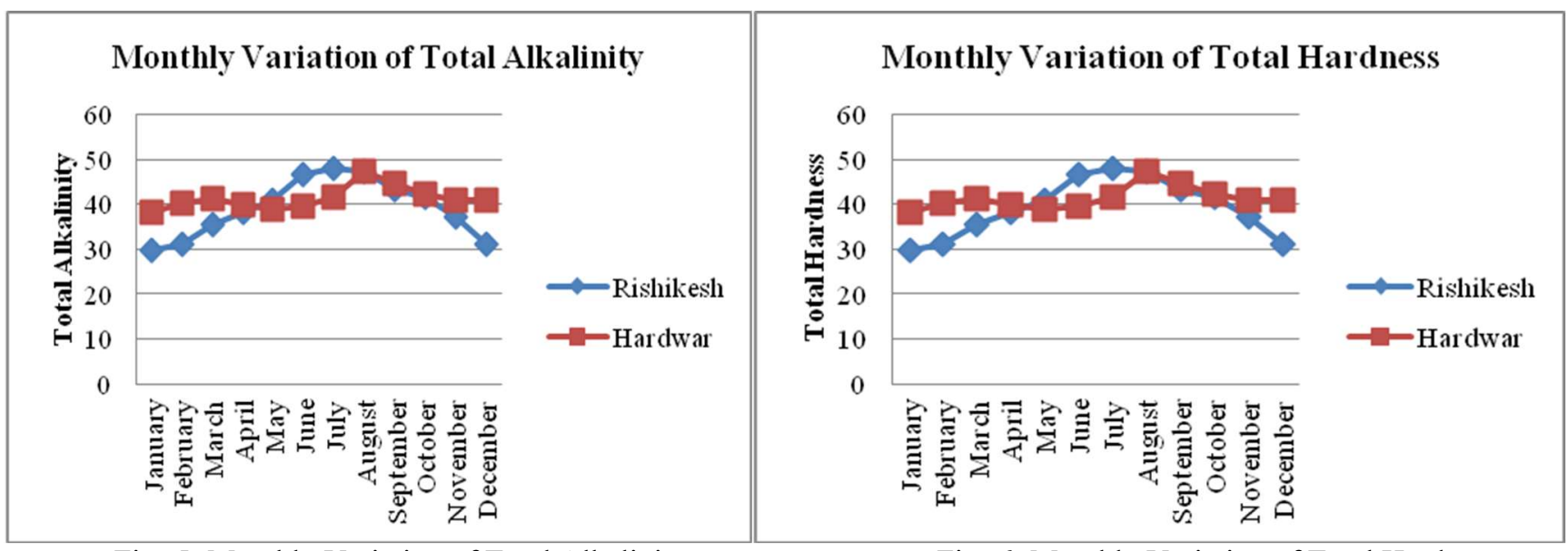

Fig.-5: Monthly Variation of Total Alkalinity

Fig.-6: Monthly Variation of Total Hardness

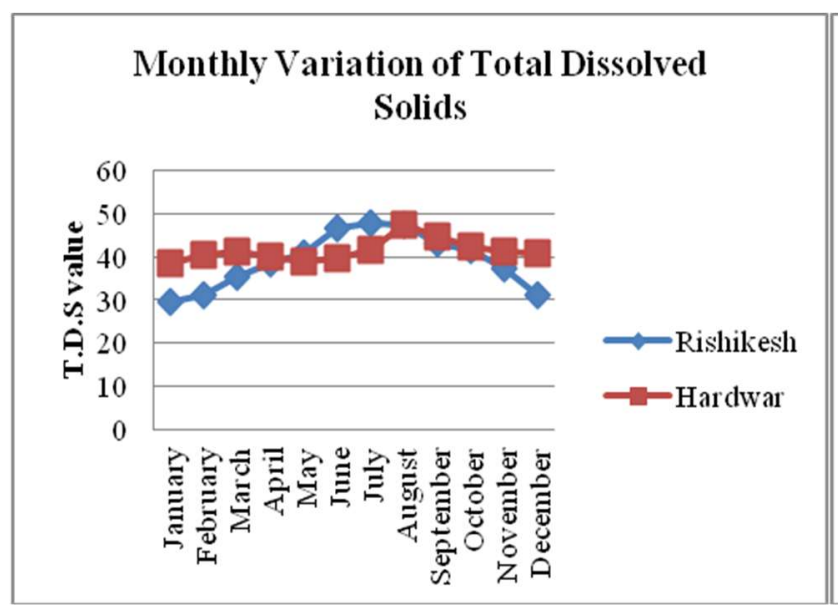

Fig.-7: Monthly Variation of Total Dissolved Solids

\section{Monthly Variation of Electrical Conductivity}

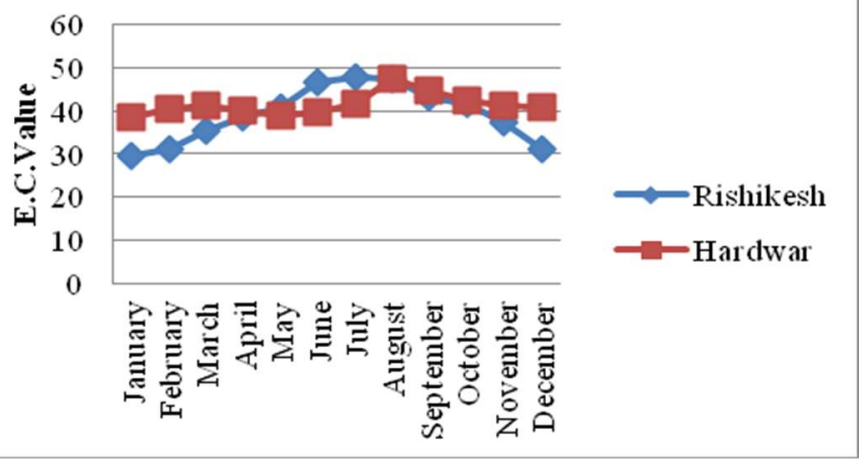

Fig.-8: Monthly Variation of Electrical Conductivity

Electrical conductivity is caused by ionic particles. As the no. of ions in the solution increases Conductivity increases. It also reveals the presence of Total Dissolved Solids and salinity in water. It shows variation with temperature as it increases by $2-3 \%$ for an increase of 1 degree Celsius of water temperature. ${ }^{23}$ The maximum E.C value $(251.79 \pm 8.01) \mathrm{micro}-\mathrm{mho} / \mathrm{cm}$ and minimum value $(205.81 \pm 7.08)$ micro-mho/cm were recorded at Rishikesh while the maximum E.C value (400.18 \pm 94.2$)$ micro-mho/cm and minimum value (224.32 \pm 3.15$)$ micro-mho/cm were recorded at Hardwar(Fig.-8). Similar results were observed by Kumar and Sharma while analyzing the Ganga River water at Koteshwar hydropower station with an average value of $(129.63 \pm 13.25) \mathrm{uS} / \mathrm{cm}^{24}$

\section{Trends in Dissolved Oxygen Saturation Percentage}

Enough dissolved oxygen is vital for good water quality. Adequate saturation is necessary for the selfpurification of the water body as well as the survival of the aquatic body. Total dissolved oxygen concentrations in the aquatic body should not exceed 110 percent and must not drop below $5 \mathrm{mg}$ /.saturation above 110 percent yields to development of "gas bubble disease" or Emphysema in fishes and invertebrates, though it is rare while below $5 \mathrm{mg} / 1$ causes stress to the aquatic organism and poor water quality. Dissolved Oxygen saturation percentages vary based on elevation, salinity and temperature of an area. ${ }^{25}$ Thus an attempt was made to identify the water quality of a river Ganga based on Dissolved Oxygen Percentage Saturation. And the results so obtained were tabulated in (Tables-5 and 6 ) respectively. Here, we considered the above-mentioned factors to determine the adequate D.O. saturation percentage required of the stream at a given area and the comparison was made with observed values. 
RASĀYAN J. Chem.

Vol. 14 | No. 3 |1643-1652| July - September | 2021

Table-5: Dissolved Oxygen Percent Saturation at Rishikesh(372m above Sea Level)

\begin{tabular}{c|c|c|c|c}
\hline Month & Temperature & $\begin{array}{c}\text { Adequate D.O. } \\
\text { Concentration(mg/l) }\end{array}$ & $\begin{array}{c}\text { Actual Dissolved } \\
\text { Oxygen Obseved (mg/l) }\end{array}$ & DO \% Saturation \\
\hline January & 15.74 & 9.81 & 10.31 & 105.09 \\
\hline February & 16.54 & 9.59 & 9.77 & 101.87 \\
\hline March & 18.74 & 9.16 & 9.25 & 100.98 \\
\hline April & 20.12 & 8.96 & 8.88 & 99.10 \\
\hline May & 21.51 & 8.67 & 8.41 & 97.00 \\
\hline June & 22.08 & 8.58 & 8.15 & 94.98 \\
\hline July & 23.17 & 8.40 & 8.03 & 95.59 \\
\hline August & 23.41 & 8.40 & 8.29 & 100.47 \\
\hline September & 23.47 & 8.40 & 8.44 & 105.82 \\
\hline October & 21.05 & 8.76 & 9.27 & 108.49 \\
\hline November & 19.68 & 9.06 & 9.83 & 113.66 \\
\hline December & 16.88 & 9.59 & 10.9 &
\end{tabular}

Table-6: Dissolved Oxygen Percent Saturation at Hardwar(Elevation-314m above Sea Level)

\begin{tabular}{c|c|c|c|c}
\hline Month & Temperature & $\begin{array}{c}\text { Adequate D.O. } \\
\text { Concentration(mg/l) }\end{array}$ & $\begin{array}{c}\text { Actual Dissolved Oxygen } \\
\text { Observed (mg/l) }\end{array}$ & $\begin{array}{c}\text { DO \% } \\
\text { Saturation }\end{array}$ \\
\hline January & 12.14 & 10.58 & 9.44 & 89.22 \\
\hline February & 15.85 & 9.72 & 9.4 & 96.70 \\
\hline March & 18.28 & 9.28 & 9.24 & 99.56 \\
\hline April & 20.71 & 8.88 & 9.02 & 101.57 \\
\hline May & 23.75 & 8.33 & 8.91 & 106.96 \\
\hline June & 25.24 & 8.16 & 8.8 & 107.84 \\
\hline July & 25.04 & 8.33 & 8.95 & 105.21 \\
\hline August & 24.57 & 8.24 & 8.67 & 102.64 \\
\hline September & 24 & 8.33 & 8.55 & 101.04 \\
\hline October & 22.24 & 8.59 & 8.68 & 100.11 \\
\hline November & 19.75 & 8.97 & 8.98 & 101.68 \\
\hline December & 16.96 & 9.49 & 9.65 &
\end{tabular}

The results so obtained depicted that water at Rishikesh is supersaturated in January to March gradually decreases to July and pronouncedly incremented from August to December at Rishikesh with a minimum value $(94.98 \%)$ in June and maximum value (113.66\% ) in December. The variation, so obtained revealed that the seasonal effect of the rainy season, the confluence of polluting sources to the river and religiotouristic activities can be the major reason for the decrease in percentage concentration of Dissolved Oxygen. However, the results depict the good self-purification capacity of River water at Rishikesh. While the results of Hardwar showed great phenomenal disparities among the monthly trends which are quite deviating as the religio-touristic activities increases from March to August. The minimum value $(89.22 \%)$, though it was satisfactory to the river water, was recorded in January while the maximum value was recorded (107.84 \%) in June, in inspite of maximum mass bathing, Religio-touristic activities and pollution as compared to the Winter season. This disparity may be due to temperature-elevation or the aeration of water due to holy dips or maximum photosynthetic activities, the reason is uncertain. Water quality of River in both the area is excellent in the terms of Dissolved Oxygen percentage saturation and so the remarkable self-cleaning potential of River water. Therefore, suitable for aquatic biodiversity and other uses. Water quality in terms of an annual average of Dissolved Oxygen percentage saturation at Rishikesh(101.81\%) as compared to Hardwar(101.66\%) is marginal or negotiable supersaturated and better but seasonal trends(Fig.-9).

\section{Integrated Water Quality Index (IWQI) Calculation}

The Integrated water quality index (IWQI) was calculated for six parameters, statistical data of which are tabulated in (Table-7). The monthly analysis of IWQI for Rishikesh and Hardwar is tabulated in (Table8). The current index is based on the desirable and permissible limits characterized by the BIS.

Seasonal variation of IWQI depicts the better comparison of water quality of the study areas is tabulated in (Table-9). 


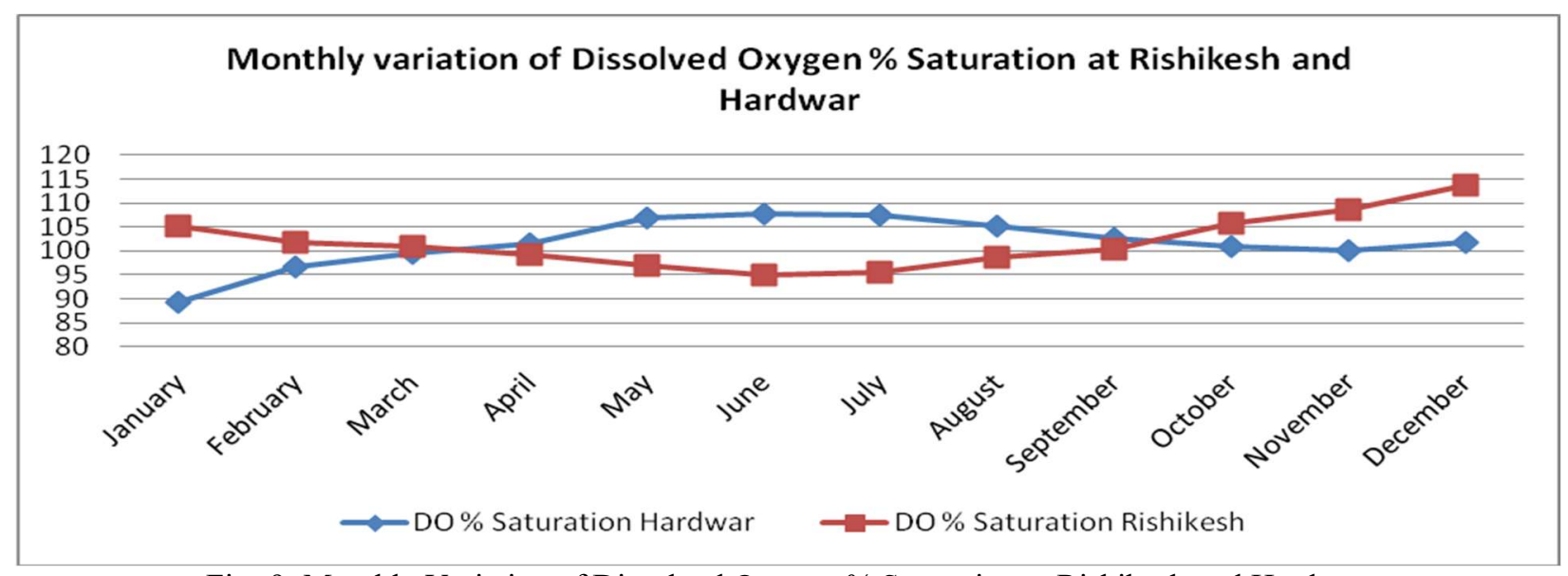

Fig.-9: Monthly Variation of Dissolved Oxygen \% Saturation at Rishikesh and Hardwar

Table-7: Statistical Data for IWQI Calculation

\begin{tabular}{c|c|c|c|c}
\hline Parameters & Desirable Limits & Permissible Limits & Range & Most Probable Limits \\
\hline $\mathrm{pH}$ & 6.5 & 8.5 & 2 & 8.1 \\
\hline B.O.D & 0 & 5 & 5 & 4 \\
\hline TA & 200 & 600 & 400 & 520 \\
\hline TH & 200 & 600 & 400 & 520 \\
\hline TDS & 500 & 2000 & 1500 & 1700 \\
\hline EC & 300 & 800 & 500 & 700 \\
\hline
\end{tabular}

Table-8: Monthly Variation Of IWQI at Rishikesh and Hardwar

\begin{tabular}{c|c|c}
\hline Month & Rishikesh & Haridwar \\
\hline January & 2.48 & 2.3 \\
\hline February & 2.4 & 2.3 \\
\hline March & 2.43 & 2.24 \\
\hline April & 2.48 & 2.35 \\
\hline May & 2.28 & 1.48 \\
\hline June & 2.25 & 1.62 \\
\hline July & 2.34 & 2.16 \\
\hline August & 2.41 & 2.34 \\
\hline September & 2.38 & 2.38 \\
\hline October & 2.43 & 1.54 \\
\hline November & 2.4 & 1.84 \\
\hline December & 2.5 & 2.16 \\
\hline \multicolumn{2}{|c}{}
\end{tabular}

Table-9: Seasonal Variation of IWQI

\begin{tabular}{c|c|c|c}
\hline Study Area & Pre-monsoon & Monsoon & Pos-tmonsoon \\
\hline Rishikesh & 2.36 & 2.39 & 2.44 \\
\hline Hardwar & 1.72 & 2.10 & 1.93 \\
\hline
\end{tabular}

The annual average results of IWQI for Rishikesh and Hardwar based on six parameters were 2.39 and 2.00 respectively. Seasonally the value of WQI varies as 2.36, 2.39, 2.44 for pre-monsoon, monsoon and post-monsoon respectively at Rishikesh while it varies as 1.72,2.10,1.93 for pre-monsoon, monsoon and post-monsoon respectively for Hardwar which indicates that water quality is disagreeable in the monsoon and post-monsoon season as compared to pre-monsoon season (Fig.-10). As the Integrated water quality Index values range from 1.48-2.5 the status of water is of good to marginal but most of the values fall to marginal water quality status and borderline to the poor quality, thus suitable for bathing and other purposes but not for drinking, hence situation is alarming as it threatens the dignity of river Ganga in its birth state. 
RASĀYAN J. Chem.

Vol. 14 | No. 3 |1643-1652| July - September | 2021

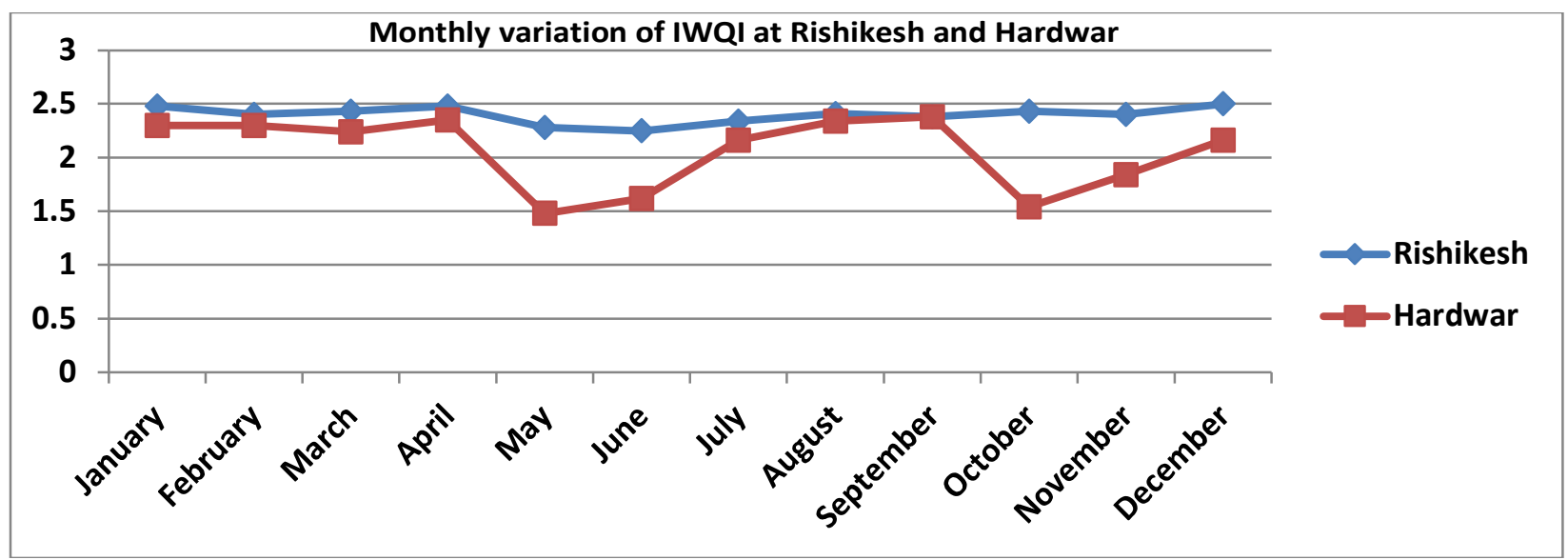

Fig.-10: Monthly Variation of IWQI at Rishikesh and Hardwar

\section{CONCLUSION}

The present analysis of River Ganga at Rishikesh and Hardwar reveals that certain phenomenal trends were observed in monthly variation of water quality. Some parametric values are borderline and are about to cross the permissible limits. IWQI so calculated reveal that the status of water quality at Rishikesh and Hardwar falls in the good to the marginal range but some values are nearly about to poor status. Comparatively water Quality at Rishikesh is better than Hardwar,site-wise parametric values reveal the prominent pollution of river Ganga near Chandrabhaga (Mayakund) and Triveni Ghat at Rishikesh, while Saptrishi, Harkipauri, Jatwada Pul water quality is in the poor condition. The water quality of these locations is still under deterioration hence from the foregoing observations of physicochemical parameters it can be summarised that the constant detailed water quality monitoring using indices and constant surveillance with effective remedial actions, of river water is the need of an hour. The holistic approach toward water management should be prioritized with the involvement of public awareness.

\section{REFERENCES}

1. R. Prasad, Asian Agri-History, 20(3), 141(2016).

2. P. K. Raji and M. Abraham, Rasayan Journal of Chemistry, 11(2), 828(2018), http://dx.doi.org/10.31788/RJC.2018.1122005

3. K. Jothivenkatachalam, A. Nithya and S.C. Mohan, Rasayan Journal of Chemistry, 3(4), 649(2010).

4. T. Ghose, Why is Water So Essential for Life? (2015).

5. M. SureshKumar, R. Sivakumar and M. Nagarajan, Rasayan Journal of Chemistry, 9(3), 454(2016).

6. P. J. Puri, M.K.N. Yenkie, D.G. Battalwar, N.V. Gandhare and D.B. Dhanorkar, Rasayan Journal of Chemistry, 3(4), 800(2010).

7. D.V. Chapman, WOH, In: Water Quality Assessments : A Guide to the Use of Biota, Sediments and Water in Environmental Monitoring, Ed. Deborah Chapman, 2nd Ed., London : E \& FN Spon, (1996).

8. B. Rai, International Journal of Scientific and Research Publications, 3(4), 1(2013).

9. D. Sharma, and S. Madan, Pollution Research, 38(2), 72 (2019).

10. R. K. Trivedy and P. K Goel, In: Chemical and Biological Methods for Water Pollution Studies, Environmental Publications, India, pp.155(2015).

11. N. Agrawal, A. Kumar and D.M. Joshi, Rasayan Journal of Chemistry, 2(1), 195(2009).

12. R. K. Trivedy and P. K Goel, In: Chemical and Biological Methods for Water Pollution Studies, Environmental Publications, India, pp.156(2015).

13. A. D. Eaton, APHA, In: Standard Methods for the Examination of Water and Wastewater, $21^{\text {st }}$ Edition, Washington, D.C. : APHA-AWWA-WEF, (2005).

14. http://dep.wv.gov/WWE/getinvolved/sos/Documents/SOSKit/DOSaturation.pdf

15. T. V. E. Wariyar, Water Quality Indexing of River Ganga between Rishikesh and Hardwar, Dissertation, (1986). http://shodhbhagirathi.iitr.ac.in:8081/jspui/handle/123456789/5608 
RASĀYAN J. Chem.

Vol. 14 | No. 3 |1643-1652| July - September | 2021

16. S. Mukate, V. Wagha, D. Panaskara, A. J. Jacobsb, A. Sawant, Ecological Indicators, 101, 348(2019), http://dx.doi.org/10.1016/j.ecolind.2019.01.034

17. D. Sharma, and S. Madan, Pollution Research, 38(2), 72(2019).

18. G. Matta, Journal of Chemical and Pharmaceutical Sciences, 7(3), 210(2014).

19. A. Wang, W. Wang, Y Liu., Sun R, and Chen L., Aquatic Toxicology, 60, 75(2002), http://dx.doi.org/10.1016/s0166-445x(01)00271-5

20. A. K. Haritash, G. Shalini, and S. Garg, Applied Water Science,6, 383(2016), https://doi.org/10.1007/s13201-014-0235-1

21. A. Wang, W. Wang, Y. Liu, R. Sun \& L. Chen, Aquatic Toxicology, 60, 75(2002), http://dx.doi.org/10.1016/s0166-445x(01)00271-5

22. G. Matta, A. Kumar, S. Bhatnagar, A. Kumar, A. Nayak and P. Kumar, ESSENCE International Journal of Environmental Rehabilation and Conservation, IX(1), 90(2018), http://dx.doi.org/10.1007/978-3-030-62397-5_17

23. D. Sharma, and S. Madan, Pollution Research, 38(2), 72(2019).

24. A. Kumar and M.P. Sharma, International Journal of Mechanical and Production Engineering, 3(8), 82(2015).

25. https://www.lenntech.com/why the oxygen dissolved is important.htm\#ixzz6KA8pVz6B

[RJC-6233/2020] 